\title{
That's what friends are for? The impact of peer characteristics on early school-leaving
}

Citation for published version (APA):

Traag, T., Lubbers, M., \& van der Velden, R. K. W. (2012). That's what friends are for? The impact of peer characteristics on early school-leaving. METEOR, Maastricht University School of Business and Economics. METEOR Research Memorandum No. 023 https://doi.org/10.26481/umamet.2012023

Document status and date:

Published: 01/01/2012

DOI:

10.26481/umamet.2012023

Document Version:

Publisher's PDF, also known as Version of record

\section{Please check the document version of this publication:}

- A submitted manuscript is the version of the article upon submission and before peer-review. There can be important differences between the submitted version and the official published version of record.

People interested in the research are advised to contact the author for the final version of the publication, or visit the DOI to the publisher's website.

- The final author version and the galley proof are versions of the publication after peer review.

- The final published version features the final layout of the paper including the volume, issue and page numbers.

Link to publication

\footnotetext{
General rights rights.

- You may freely distribute the URL identifying the publication in the public portal. please follow below link for the End User Agreement:

www.umlib.nl/taverne-license

Take down policy

If you believe that this document breaches copyright please contact us at:

repository@maastrichtuniversity.nl

providing details and we will investigate your claim.
}

Copyright and moral rights for the publications made accessible in the public portal are retained by the authors and/or other copyright owners and it is a condition of accessing publications that users recognise and abide by the legal requirements associated with these

- Users may download and print one copy of any publication from the public portal for the purpose of private study or research.

- You may not further distribute the material or use it for any profit-making activity or commercial gain

If the publication is distributed under the terms of Article $25 \mathrm{fa}$ of the Dutch Copyright Act, indicated by the "Taverne" license above, 


\section{Maastricht University}

Tanja Traag,

Miranda Jessica Lubbers,

Rolf van der Velden

That's what friends are for? The impact of peer characteristics on early school-leaving

$\mathrm{RM} / 12 / 023$

\section{METEOR}

Maastricht University School of Business and Economics

Maastricht Research School of Economics

of Technology and Organization

\section{P.O. Box 616}

NL - 6200 MD Maastricht

The Netherlands 


\title{
THAT'S WHAT FRIENDS ARE FOR? THE IMPACT OF PEER CHARACTERISTICS ON EARLY SCHOOL-LEAVING ${ }^{1}$
}

\author{
Tanja Traag ${ }^{2}$, Miranda Jessica Lubbers ${ }^{3}$, and Rolf van der Velden ${ }^{4}$
}

\begin{abstract}
In this paper we investigate if peer relations affect a student's risk of early school-leaving. We use the sociometric data collection from the Dutch "Secondary Education Pupil Cohort 1999" to identify peer relations in a sample of almost 20,000 students in the first grade of secondary education (mean age 13). This information is matched to data on educational attainment from 1999 to 2010 for these students, to measure later early school-leaving by both the focal students as well as their peers. Our results show that both being friends with future early school-leavers as well as popularity among future early schoolleavers increases the risk of students to be early school-leavers later in their educational career while other characteristics of the peer group such as gender composition, ethnic composition, average (non)cognitive skills and average socioeconomic background have no effects on the risk of early schoolleaving. And while characteristics like gender, ethnicity and socio-economic background play an important role in peer selection, the future dropout status does not have a major impact on peer selection.
\end{abstract}

Key words: peers, school-performance, early school-leaving

JEL codes: I20, I21 en I24

\footnotetext{
${ }^{1}$ We would like to thank Roxanne Korthals, Olivier Marie for their helpful comments.

2 Statistics Netherlands

3 Autonomous University of Barcelona

${ }^{4}$ Research center for Education and the Labor Market
} 


\section{Introduction}

Early school-leaving has a lasting influence on an individual's life course. It increases the risk of unemployment and low-paid jobs (Beckers \& Traag, 2005a, 2005b; Rumberger, 1987), the risk of dependency on social security benefits, and it also correlates with higher levels of delinquency (Thornberry, Moore, \& Christenson, 1985; Traag, Marie, \& Van Der Velden, 2010). The majority of the existing literature reflects an individual deficit model, focusing primarily on individual and family characteristics as the major causes of early school-leaving (Hymel, Comfort, Schonert-Reichel, \& McDougall, 1996; Ream \& Rumberger, 2008), while ignoring the importance of peer relations for school engagement. In this paper, we investigate whether peer relations influence a student's risk of early schoolleaving. A large number of studies demonstrate the impact of peer relations on academic performance. Some argue that students who feel accepted by their peers are better able to meet academic challenges (Furrer \& Skinner, 2003; Lubbers, Van der Werf, Snijders, Creemers, \& Kuyper, 2006; Patrick, Ryan, \& Kaplan, 2007; Walters \& Bowen, 1997). Also, it is argued that the characteristics of peers influence academic performance, because students observe and model other students' learning styles (Bandura, 1977), evaluate their achievement by comparing it to others (specifically with friends, Lubbers, Van der Werf, \& Kuyper, 2009) and are rewarded for behaviour that is valued by peers (Wentzel, 1996). Peer relations in classrooms have been associated with grades (Wentzel, 2003; Zettergren, 2003) ${ }^{5}$, scores on achievement tests (Buhs \& Ladd, 2001) ${ }^{6}$, and graduation rates (Risi, Gerhardstein, \& Kistner, 2003).

Although academic performance is highly correlated with early school-leaving, studies on the relevance of peers for early school-leaving are rather limited. In this study, we want to contribute to the existing literature in three ways.

First of all, large-scale empirical research on the impact of peer characteristics on early schoolleaving is rather limited. Cairns et al. (1989) used a prospective longitudinal study of 475 US students that included individual interviews to map social networks to identify affiliations with peers who were vulnerable to subsequent school drop-out. Their study showed that for both boys and girls in seventh grade, school drop-outs affiliated with peers who themselves later dropped out of school. However, Cairns and colleagues did not add any controls for academic and family factors. A study by Vitaro, Larocque, Janosz and Tremblay (2001) among Caucasian boys in Canada showed that while socio-economic

\footnotetext{
${ }^{5}$ For additional literature see Guldemond (1994), Ollendick, Weist, Borden, \& Greene (1992), Wentzel \& Caldwell (1997) and Wigfield, Eccles, \& Rodriguez (1998).

${ }^{6}$ Also see Diehl, Lemerise, Caverly, Ramsay, \& Roberts (1998), Ladd, Kochenderfer, \& Coleman (1997), Vandell \& Hembree (1994) for literature on the relationship between peers and achievement scores.
} 
background and personal dispositions had a direct impact on high school drop-out, unpopularity/friendlessness (peer rejection) had no impact. However, association with deviant friends (i.e. friends who were arrested by the police, were member of a gang and/or considering to leave school) did have a significant impact on high school drop-out. Peer deviance was measured by questions to respondents about exposure to deviant drop-out friends. Although this study does bring about some interesting results, generalisation of the results may be limited since the study was conducted exclusively among white males. Also, the measurement of unpopularity/friendlessness used was quite unconventional. In 2008, a study by Ream and Rumberger (2008) showed that the number of drop-out friends significantly increased the risk of school drop-out in twelfth grade, suggesting that friends act as a prototype for subsequent processes, influencing educational attainment and school drop-out. However, the measurement of peer relations and the measurement of peer characteristics in this study were rather limited. Peer dropout was measured by students' responses to the question how many of their close friends had dropped out, yet no true peer relations were established, so they were unable to add any controls for other peer characteristics. Our first contribution to the current literature is that we will use a very unique dataset which allows us to better analyse how exposure to future early school-leavers increases one's own risk of early school-leaving above and beyond characteristics of both the student and their peers. We will use a large scale longitudinal panel study of almost 20 thousand Dutch students in the first grade of secondary education in 1999. We will focus on characteristics that predict a student's own risk of early schoolleaving as well as the peer's future drop-out status. Peer relations were measured by asking students to nominate classmates whom they liked best. In the analysis we match individual characteristics with peer characteristics like gender, ethnicity, socio-economic background, cognitive and non-cognitive skills, and future drop-out status. In line with past research we expect that students who associate with future schoolleavers are more likely to become an early school-leaver themselves. In addition, we expect that peers' school performance, achievement motivation and social class all have a positive impact on the probability of attaining a full upper secondary qualification.

Our second advancement is that relatively few studies have analysed the relevance of the concepts of both popularity and number of friends for educational attainment at the same time (Farmer, Estell, Leung, Trott, Bishop, \& Cairns, 2003; Ream \& Rumberger, 2008; Vitaro et al., 2001). Moreover, these few studies produced mixed results. While some authors found additive effects (Diehl, Lemerise, Caverly, Ramsay, \& Roberts, 1998; Vandell \& Hembree, 1994), others found redundant relations. A possible explanation for these mixed results was given by Ladd et al. (1997), who suggested that patterns of association between number of friends, peer acceptance and outcome variables differ depending on the outcome measures. We will distinguish between two - partially overlapping - peer groups, namely those who were nominated by our focal respondents as best liked classmates (non-reciprocal as well as 
reciprocal friends) and those who nominated our focal respondents (the peer group determining students' popularity). We then test whether the characteristics of these two groups affect the students' probability of early school-leaving.

Our third advancement on previous studies is that we address the complex issue of providing evidence of peer effects, above and beyond alternative processes that might explain peer similarity. Similarity may be a product of homophily, which refers to the tendency of people to associate with others who are very much like themselves. A large body of empirical evidence (see McPherson, Smith-Lovin, \& Cook, 2001) suggests that people initially select each other based on visible traits and then choose their friends from the resulting group of similar others (Lubbers et al., 2006). Homophily is a pervasive organising principle of social relationships. This makes it difficult to disentangle the causal direction between peer relations and the similarity between peers. In this study, we therefore performed some robustness analyses to understand to what extent pairs (or dyads) are formed on the basis of homophily. To do this, we performed an analysis of all possible dyads within classes. Specifically, we regressed the probability that a pair is in a friendship relation on the similarity between the students in the pair on a number of predictors of early school-leaving (Traag \& Van der Velden, 2011), such as cognitive skills, motivation and social class indicators. In a second step, we added the similarity in future school-leaving status as a predictor, to study whether having the same future school-leaving status affects the probability of forming a friendship relation. If unobserved characteristics affect both the forming of a relationship and the risk of becoming an early school-leaver, adding the future school-leaving status will have a strong effect on the probability that this pair is in a friendship relationship. If this is not the case, then we can have more confidence in the causality of our results. A second explanation of dyadic similarity in early school-leaving and academic characteristics related to early school-leaving can be found in the practice in Dutch education to group children together in classes based on their cognitive skills, again making it more likely for children who are very much the same on a number of characteristics to have a friendship relation. This again, makes it harder to distinguish between the mere effect of selection and the true influence of peers. We use a random coefficient model that takes into account the clustering of our data into schools and classes and controlled for the track level.

The main findings are that friendship and popularity have additive effects. Having friends who later become early school-leavers as well as being popular among future early school-leavers increases a student's own risk of becoming an early school-leaver. We will show that this is a mere effect of peer selection. Other characteristics of the peer group such as gender composition, ethnic composition, average cognitive and non-cognitive skills, and average socio-economic background have no effects on the risk of becoming an early school-leaver but some of these characteristics do play a role in peer selection. 
This paper is structured as follows. In section 2 we discuss our data and the variables used. This section also includes the analytical strategy and methodology used. In section 3 we discuss our results from the descriptive analyses and the random effect models. Section 4 concludes with a discussion of our findings and addresses some issues for future research.

\section{Data and study design}

Data were collected as part of the large-scale study "Secondary Education Pupil Cohort 1999" (VOCL'99), carried out by the Groningen Institute for Educational Research (GION) and Statistics Netherlands (CBS). The study followed a cohort of students who entered secondary education at the age of 12 until they leave full-time education. The initial sample consisted of 19,391 students in 825 classes from 126 schools who entered secondary education in the 1999/ 00 school year. The sample is representative for schools and students in Dutch secondary education (Kuyper, Lubbers, \& Van der Werf, 2003).

From our initial sample of 19,391 students we excluded students who had died, were seriously ill or had moved abroad in the period between 1999/ 00 and 2010/ 11 (473 students). In addition, we excluded students in classes that had response rates below 80 percent on the sociometric questionnaire (8,020 students). This left 10,898 students for our analyses. This selected sample differs a little bit from the initial cohort population. The average age of this sample is 12.5 years $(S D=.48)$ at the first measurement, $54.3 \%$ of this sample is female, $8.8 \%$ is first or second-generation non-western migrants, and 50.7 started education in pre-vocational education. In the unselected sample of 19,931 students, the average age is 12.6 years $(\mathrm{SD}=.51), 50 \%$ is female, 11.5 is first or second generation non-western migrants, and $56.5 \%$ is in the pre-vocational track at age 12 . Since our selection is slightly biased towards students from higher educational tracks, females and native students, those less at risk of early schoolleaving are overrepresented in this subsample. This will have a conservative effect on the results.

\subsection{Measures}

\subsubsection{Early school-leaving}

In this paper, an early school-leaver is defined as a student who did not have a full upper secondary qualification in September 2010 (in the school year 2010/ 11). This is considered the minimum level of education a person should acquire to be successful on the labour market: the 'basic qualification' ('startkwalificatie' in Dutch) (OECD, 2007). This concept does not amount to an actual certificate, but is widely used for political and research purposes to identify youths with low education achievement. To aid understanding of the operationalization of early school-leaving, we will first shortly explain the Dutch education system, which is very stratified (for an overview, see Appendix 1). After 8 years of primary education, students enter secondary education at the age of 12 . Here they are placed in one of three tracks: 
one track preparing for university education (VWO, duration 6 years), one for higher vocational education (HAVO, duration 5 years), and one for vocational education at the upper secondary level (VMBO, duration 4 years). Track placement is decided on the basis of a nationwide CITO test at the end of primary education and the advice of the primary school teacher. A full upper secondary qualification is defined as a diploma from the pre-university track, the pre-college track, or a diploma at the level of at least upper secondary basic vocational education. This means that early school-leavers are students who attained no diploma at all, or a diploma at the level of the pre-vocational track or at the level of vocational assistant in upper secondary education. In our sub-sample, 2,060 (18.9 percent) students had not attained this minimum level of education. The risk of becoming an early school-leaver is largest for those who started their educational career in the pre-vocational track (see Table 1), 27.4 percent of these students did not attain a full upper secondary qualification. For those who started in the tracks preparing for vocational colleges or university, the risk is much smaller. Only 8.4 percent of students who started in the pre-college track and 5.0 percent of those who started in the pre-university track did not attain a full upper secondary qualification.

\section{$<$ Table 1 about here $>$}

\subsubsection{Individual and family characteristics}

In our models we controlled for a number of characteristics that were shown in a previous study (Traag \& Van der Velden, 2011) to predict early school-leaving:

School performance ${ }^{7}$ is a sub-test of the test used at the end of primary education to determine track placement. The test consists of three subtests for text comprehension, arithmetic and information processing (see Lubbers, 2004, for a detailed description of the testing procedure). Each test has 20 multiple-choice items ${ }^{8}$. For comparability purposes, this and all other scale variables used were rescaled so that the lowest score was 0 and the highest score was 1.

\footnotetext{
${ }^{7}$ In January 2000 (four months after their entry into secondary education), the students completed a school performance test, a student questionnaire and a sociometric questionnaire while in their regular classes. They were assured that the information in the survey would be kept confidential. Students who were absent on the day the questionnaires were administered are treated as missing cases. The school performance test was developed by the Cito Group (the Dutch equivalent of Educational Testing Services). The test was taken in class, under the supervision of one or more teachers, mostly the class tutor, and took up two full periods. A total of 1,216 students did not participate in any of the tests, while 377 students filled out one or two. A total of 91.8 percent of the students participated in the school performance test.

${ }^{8}$ The reliability of the total test is $\alpha=.90$, which reflects the intercorrelation between the items incorporated in the scale. As a general rule of thumb, tests with $\alpha>=.90$ are considered excellent; tests with $\alpha>=.70$ are considered good while and $\alpha$ below .50 is considered unacceptable.
} 
School motivation was measured in January 2000 in the student questionnaire ${ }^{9}$ using the Academic Achievement Motivation Test (Hermans, 1970) that assesses a student's motivation to perform well in school. The scale consists of 9 items ${ }^{10}$ indicating the responses to questions like: "I do my homework much better when I'm worried about failing" and "I always try to do my homework as well as possible". Previous studies have shown motivation to be a key predictor of academic attainment (Hustinx, Kuyper, M.P.C. Van der Werf, \& Dijkstra, 2009; Kuyper, Dijkstra, Buunk, \& Werf, 2011; Kuyper, Werf, \& Lubbers, 2000).

Parental education was collected in the parental questionnaire ${ }^{11}$ during the school year 1999/ 00 . For both parents (if available) the highest education level was recoded into the number of years of schooling needed to obtain this level (Bosker, Van Der Velden, \& Hofman, 1985) varying from 6 (primary education) to 19 years (university). To reflect the parental education level the mean of the father and the mother was taken.

Parental income is measured as the log of the mean personal income of both the father and the mother (if available) in 2004 and was taken from the Annual Income Registry kept by Statistics Netherlands based on information from the Dutch Tax Administration. It includes income from labour as well as social security benefits and other sources of income. For single parent households, only the income of the resident parent was used. Parents with zero or negative income (124 cases in the initial population) were recoded to having zero income ${ }^{12}$. Where the income could not be matched (702 cases in the initial population), the income was replaced by the population mean.

Parental communication is based on three questions ${ }^{13}$ to both parents in the parental questionnaire on talking to their child about school and their performance. It includes items such as "How often do you or your partner talk to your child about things your child learned in school?"”

\footnotetext{
9 The student questionnaire was also administered in class, mostly during the tutor class. The questionnaire contained questions on, among other things, school motivation, learning strategies, school well-being, class climate and truancy. Since most schools took the student questionnaire on the same day as the school performance test and the sociometric questionnaire, there is a high correlation between the non-response on these items. The overall response rate for the students questionnaire is 94 percent.

10 The reliability of the scale is .74 , which can be considered a good, internally consistent scale.

${ }^{11}$ To obtain information from the parents, a parental questionnaire was given to the students. Completed questionnaires could either be returned to the school or directly to Statistics Netherlands, again assuring confidentiality. The overall response rate for this questionnaire was 82 percent. The parental questionnaire had two aims. First, it was designed to measure variables in the home environment that affect school performance of the children, such as parenting styles, parental involvement, and aspirations. Second, the socio-economic status of the household was measured by asking questions on parental education and occupation. ${ }^{12}$ Negative or zero incomes occur in those cases where parents are self-employed and made no profits or suffered losses during the observation period.

${ }^{13}$ The reliability of the scale is .64 , which is considered a good internal consistency.
} 
Gender is coded 0 for boys and 1 for girls.

Migrant status is based on the Municipal Population Registration (GBA) and is coded 0 for native Dutch and 1 for migrant. A respondent is defined as a 'migrant' if he/she was born abroad or at least one of his/her parents was born abroad.

Item non-response was replaced by the mean score of the sub-population in the same class. For each variable a dummy was included with value 1 if data were replaced and value 0 when data were not replaced.

\subsubsection{Peer group characteristics}

As part of the sociometric questionnaire, students were asked to nominate classmates whom they liked best (maximum 3 nominations). For each nomination, the student was asked to report the surname and the first initial of the nominee. This resulted in 38,041 nominations for 14,271 students. These names were then transformed into their corresponding identity numbers using an automated procedure. In a few cases, we were not able to match a nominee's name to an identification number for the following reasons. First, notwithstanding the request to only nominate children within their classes, some students nominated persons outside their classes. Secondly, some students did not fill in a full surname, but only used initials. These nominations could only be matched if the combination of initials was unique within that class. Thirdly, some students wrote things like "all boys in my class", or "none" instead of a name. These cases were coded as missing values.

Popularity. Popularity was operationalised as the number of times students were nominated by their classmates as 'best liked' (hence peer-reported). We estimate the effects of both being popular among future early school-leavers as well as being popular among future regular school-leavers. These variables were measured as the number of nominations received by future early school-leavers and future regular school-leavers, respectively. School-leaving status of peers was measured in the same way as for the focal respondents.

Number of friendships. A classmate is defined as a friend if the respondent nominated that person as 'best liked'. In most studies on the impact of friendship, only those dyads are classified as friends where the nomination is reciprocal. Studies using reciprocal nominations as a measure for friendship (Bukowski \& Hoza, 1993; Vandell \& Hembree, 1994) stress that the use of such a measure represents a conservative test of the hypothesis that peer acceptance and friendship are unique contributors to adjustment because of the inherent overlap in the measures. In the present study we will concentrate on an analysis that includes both reciprocal and non-reciprocal friends, because as only a maximum of three nominations could be given, requiring reciprocity would be a very strict measure of peer relations. However we repeated the analysis using only reciprocal friends. This analysis yielded the same 
substantive results. ${ }^{14}$ To estimate the effects of having friends among future early school-leavers and future regular school-leavers, we include the number of future early school-leaving and future regular school-leaving friends in our models. Again, the school-leaving status of friends is measured in the same way as described earlier.

To control for characteristics of both nominated and nominating peers, we computed a number of variables that reflect the characteristics of the peer group. For performance, motivation, parental education, parental income, and parental communication, we calculated the mean score of the peer group. For gender, we used the percentage of males in the peer group and for migrant status, the percentage of migrants.

In the second part of our analyses, we test the impact of similarity among peers on the probability that one peer nominates the other, using the characteristics described above. For this procedure, we calculated a set of dummies indicating whether students were the same (1) or not (0) on gender, migrant status and school-leaving status. For continuous variables (i.e. school performance, school motivation, parental education, parental income, and parental communication), we first computed tertiles for both the focal student and the peer and then computed dummy variables indicating that they were in the same tertile (1) or not (0). We use these dummies to predict the probability that within a dyad one peer nominated the other.

\subsubsection{Class- and school-level characteristics.}

We also include a number of school-level predictors in our model that were shown to affect early schoolleaving in our previous study (Traag \& Van der Velden, 2011).

The school's heterogeneity is divided into four categories:

- schools that only provide the pre-vocational track,

- schools that provide all three tracks,

- schools that provide only the pre-college and the pre-university track,

- schools that provide only the pre-university track.

We will use three dummy variables to represent this variable; the first category serves as the reference category.

\footnotetext{
14 As a robustness check, we replicated our study using only reciprocal friends. Of course, the distribution of these variables is much more skewed than in the less stringent sample, with 28.5 percent of all students having no friends at all compared to 7.2 percent for non-reciprocal friends. However, findings based on reciprocal friendships are very comparable to the findings in this study. The results of the robustness check are described in appendix 4.
} 
The percentage of migrant students is computed by dividing the total number of migrants in the sample in the school by the total number of students in the sample in that school.

The degree of urbanisation is based on the number of addresses per square $\mathrm{km}$ in the school region. For our analyses, this variable was coded (1) fewer than 500 addresses, (2) 500-1,000 addresses, (3) 1,000-1,500 addresses, (4) 1,500-2,500 addresses, and (5) 2,500 addresses or more.

In addition, we control for the number of students within a class and the education track, with two dummies for the pre-college track and the pre-university track (pre-vocational track is the reference category). Appendix 2 gives the descriptive statistics of all variables used in the analyses while appendix 3 gives the zero-order correlations for the individual variables used in our models.

\subsection{Analytical strategy}

We estimated a series of random effect models that include individual, peer and class characteristics. The reason random effect models are chosen is that students are not randomly assigned to classes, as the composition of classes is partly based on students' cognitive skills. Therefore, we expect early schoolleaving not only to differ on their individual characteristics, but also on class characteristics. Therefore, we used a random coefficient logit model that estimates the risk that a student ${ }_{i}$ in a class ${ }_{j}$ will become an early school-leaver, allowing the intercept to have random effects among classes:

$\operatorname{logit}\left(p_{i j(\text { dropout }=1)}\right)=\beta_{0 j}+\sum_{h=1}^{m} \beta_{1 h} S_{i j}+\sum_{h=1}^{m} \beta_{2 h} P_{i j}+\sum_{h=1}^{m} \beta 3_{h} F_{i j}+\sum_{h=1}^{m} \beta_{4 h} C_{i j}$ with $\beta_{0 j}=\beta_{0}+y_{i j}+u_{0 j}$

where $\mathrm{S}=$ student and family characteristics

$\mathrm{P}=$ characteristics of those who nominated the student

$\mathrm{F}=$ characteristics of those who were nominated by the student

$\mathrm{C}=$ characteristics of the class/school

As discussed above, the effect of peer characteristics might be caused by unobserved heterogeneity in the peer selection process instead of true peer influence. Therefore, we ran an additional random effect model (see Section 3.3) in which we estimated the probability that within all possible dyads $d$ within the classes in our sample, at least one of the two students will nominate the other, based on similarity on a number of characteristics by using model (2a). First we estimated the probability of at least one student selecting the other within dyad $d$ on the basis of similarity in a number of student and family characteristics. For dichotomous variables these are coded (1) if they were similar and (0) if they were not similar. For continuous variables we first computed tertiles for both the focal student and the peer and then computed dummy variables indicating that they were in the same tertile (1) or not (0).. This model shows to what 
extent the similarity of personal and family characteristics affect a student's choice of peers.

$$
\begin{aligned}
& \operatorname{logit}\left(p_{i j(\text { peersimilarity=1) }}\right)= \\
& \beta_{0 j}+\sum_{h=1}^{m} \gamma_{1 h} G_{d j}+\sum_{h=1}^{m} \gamma_{2 h} M S_{d j}+\sum_{h=1}^{m} \gamma_{3 h} S P_{d j}+\sum_{h=1}^{m} \gamma_{4 h} S M_{d j}+\sum_{h=1}^{m} \gamma_{5 h} P E_{d j}+\sum_{h=1}^{m} \gamma_{6 h} P I_{d j}+\sum_{h=1}^{m} \gamma_{7 h} P C_{d} j \\
& \text { with } \beta_{0 j}=\beta_{0}+y_{i j}+u_{0 j} \\
& \text { where } \quad \mathrm{G}=\text { gender } \\
& \quad \mathrm{MS}=\text { migrant status } \\
& \quad \mathrm{SP}=\text { school performance } \\
& \quad \mathrm{SM}=\text { school motivation } \\
& \mathrm{PE}=\text { parental education level } \\
& \mathrm{PI}=\text { parental income } \\
& \mathrm{PC}=\text { parental communication }
\end{aligned}
$$

In the second model $(2 b)$ we added the similarity in school-leaving status to analyse whether this affects the predictive quality of our choice of peers model, by comparing the pseudo $\mathrm{R}^{2}$ to the first model (model $2 a)$.

$\operatorname{logit}\left(p_{i j(\text { peersimitrity=1) })}\right)=$

$\beta_{0 j}+\sum_{h=1}^{m} \gamma_{1 h} G_{d j}+\sum_{h=1}^{m} \gamma_{2 h} M S_{d j}+\sum_{h=1}^{m} \gamma_{3 h} S P_{d j}+\sum_{h=1}^{m} \gamma_{4 h} S M_{d j}+\sum_{h=1}^{m} \gamma_{5 h} P E_{d j}+\sum_{h=1}^{m} \gamma_{6 h} P I_{d j}+\sum_{h=1}^{m} \gamma_{7 h} P C_{d} j+\sum_{h=1}^{m} \gamma_{8 h} S L S_{d} j$

with $\beta_{0 j}=\beta_{0}+y_{i j}+u_{0 j}$

where SLS = similarity in school-leaving status

\section{Results}

\subsection{Descriptive results}

The average rate of popularity among future regular school-leavers is 2.6 nominations. As shown in Figure 1, this is higher than the popularity among future early school-leavers, who received only 2.3 nominations. Popularity among future early school-leavers is slightly higher among future early schoolleavers (.8) than among regular school-leavers (.4). Popularity among future regular school-leavers is higher for the future regular school-leavers (2.2) than for the future early school-leavers (1.5).

\section{$<$ Figure 1 about here $>$}

$<$ Figure 2 about here $>$ 
Figure 2 shows an almost identical picture for friendship. Future early school-leavers have in general fewer friends (2.4) than future regular school-leavers (2.6) . Future early school-leavers had significantly higher numbers of friends among other future early school-leavers (.8) than future regular school-leavers (.3). As can be expected, future regular school-leavers have more friends among other future regular school-leavers (2.2) compared to future early school-leavers (1.7). Thus we can conclude that there is indeed a relationship between a student's own future school-leaving status and their peer's. Students that become early school-leavers more often tend to be related to peers with a similar school-leaving status.

\subsection{The impact of peer characteristics on early school-leaving}

To estimate the effect of peers on early school-leaving, we used our sample of 10,898 observations within 579 unique classes across 120 schools. To correct for the clustering of students in classes, we applied a random coefficient model that allows the constant to be random (see Section 2.2). We ran a series of models, adding blocks of variables to the model while excluding others. Lastly, we ran a full model including characteristics of the individual, the friends, those who nominated our respondent and some class level predictors. We start with a model that contains only individual characteristics, serving as a baseline model that shows which variables predict the risk of early school-leaving. Table 2 shows the results.

As we have seen in our previous study (Traag \& Van der Velden, 2011), being male increases the risk of early school-leaving by 54 percent (logit=.432***) while being a migrant decreases it by 72 $(\operatorname{logit}=-.329 * * *)^{15}$. School performance $\left(\operatorname{logit}=-2.818^{* * *}\right)$, school motivation $\left(\operatorname{logit}=-.478^{* *}\right)$, parental education $\left(\operatorname{logit}=-.088^{* * *}\right)$, parental income $(\operatorname{logit}=-.104 * *)$, and parental communication $(\operatorname{logit}=-.331 *)$ all significantly reduce the risk of early school-leaving. To illustrate these effects: for school performance, the risk of becoming an early school-leaver is .723 for a reference person, i.e. native females in a prevocational track, with average scores on school performance, school motivation, parental education, parental income, and parental communication, who were in a school in an average urbanized region, with an average percentage of ethnic minorities, with an average class size, and a school that only provides prevocational education. When school performance increases with one standard deviation, the risk of becoming early school-leaver for this reference person is decreased to .612 .

In addition, we find some effects of school and class characteristics. As expected, we find strong effects for the track level at age 12, with the pre-college and pre-university tracks showing significantly lower risks of becoming an early school-leaver. In addition, schools that provide other tracks of education

\footnotetext{
${ }^{15}$ Note that we only find such a protective effect of having a migrant background after controlling for parental characteristics and the percentage of migrant students at the school level. Without such controls the effect would have been positive (logit=.057; not reported in the model), indicating that migrant students have a higher chance to become an early school-leaver.
} 
than the pre-vocational one have lower early school-leaving rates than schools that only provide the prevocational track. The degree of urbanisation has a positive effect (logit=.092***), indicating that the risk of leaving school early is higher in more urbanised areas. Also attending schools with a high percentage of migrant students increases the risk of early school-leaving (logit $=.634^{* *}$ ). Lastly, the size of the class has a small negative effect (logit $=-.003$ ) but this effect is not significant. However, based on the intraclass correlation, we can conclude that the variance explained at the school and class level is very small.

In model, 2a characteristics of those who nominated the students are added to the model. The results show that the characteristics of those who nominated the focal student add only small effects to the risk of an individual becoming an early school-leaver beyond the individual characteristics of the student and our other control variables. Being popular among those who perform well in school as well as those with high educated parents has a negative effect, while being popular among those with high parental income increases the chance the chance to leave school early. However, these effects are only marginally significant $(\mathrm{p}<.10)$.

In model $2 \mathrm{~b}$ we add popularity among future early school-leavers as well as popularity among future regular school-leavers to the model. This reduces all peer characteristics and causes them to become non-significant. Being popular among future regular school-leavers reduces the risk of leaving school early by 12 percent (logit=-.131***). At the same time, being popular among future early school-leavers increases the risk of becoming an early school-leaver oneself by 17 percent (logit=.159***).

Model 3a estimates the risk of becoming an early school-leaver based on individual traits and the characteristics of friends. Again, we find that having friends with high educated parents decreases the risk of becoming an early school-leaver by 4 percent for every additional year of education of these parents and this effect is highly significant (logit=-.040***). Again we find a small positive effect of these friends's parental income, but the effect is only significant at the $10 \%$ level. In model $3 \mathrm{~b}$ we add the school-leaving status of the friends as predictors to our model. Having many friends among regular school-leavers is negatively linked to becoming an early school-leaver, although the effect is not significant (logit=-.012). Having friends among future early school-leavers clearly increases the chance to become an early school-leaver oneself (logit $=.232 * * *)$ as was expected.

In our last model, we added all variables for the individual, nominators, friends, and the school *class. Again, we find a significant negative effect of being popular among future regular school-leavers $\left(\operatorname{logit}=-.120^{* * *}\right)$ and a significant positive effect of popularity among future early school-leavers (logit $=.101^{* *}$ ). At the same time, we find a positive effect of having friends among future early schoolleavers (logit $=.168^{* * *}$ ), while the effect of having friends who are future regular school-leavers is very small and not significant (logit=.047). Peer characteristics have hardly any additional effect in this last model, since most of the effect is captured by controlling for the school-leaving status of the peers. 


\subsection{Predicting peer selection}

Since people tend to choose their peers based on similarity, it is difficult to separate effects of peer selection from peer influence. To enable us to assess whether early school-leaving of peers has a causal effect on a student's own risk of leaving school early, we investigated how the probability that one peer selects the other as someone they liked is predicted by similarity on a number of characteristics, such as gender, migrant status, cognitive and non-cognitive skills and measures of social class. From our student sub-sample of 10,898 students, we computed all possible unique dyads or possible peer relations, resulting in 113,835 dyads. For each dyad, we compared the characteristics of the two students to assess whether they are the same or not, as described in section 2.2. Table 3 shows the rate of similarity within dyads for the variables used in our previous models. For example, the table shows that within the total group of possible dyads, 58 percent is of the same gender. However, when we look at the dyads where one peers chose the other as someone they liked, 96 percent has the same gender. As the table shows, students who selected one another are almost always the same in gender. They also tend to be slightly more similar in migrant status, school performance, school motivation, and parental education, than students who did not select one another. For parental income, and parental communication and early school-leaving status, differences in similarity are not significant at the 99 percent level.

\section{$<$ Table 3 about here $>$}

Next we estimated two random effect models where the outcome variable was the probability that at least one person in this dyad had indicated the other as someone they liked, predicted on the basis of similarity in individual characteristics. The results are presented in table 4.

Our results from model (1) show that especially similarity in gender, and to a minor extent also similarity in migrant status, school performance, school motivation, parental education, parental income, and the parents talking to children about school increase the likelihood of a friendship relation being formed in a dyad. In model (2), we add the similarity in school-leaving status to the model. Results for all other variables hardly change and similarity in school-leaving status has a small but significant positive relationship with the selection of peers. More specifically, dyads that are similar in school-leaving status are $\mathrm{e}^{.112}=1.12$ times more likely to nominate the other as peer than dyads that are not similar in schoolleaving status, net of the other effects. This seems to suggest that future early school-leavers are more likely to associate with other future early school-leavers, and future regular school-leavers are more likely 
to associate with other future regular school-leavers. However, adding similarity in future school-leaving status results only in a very small improvement of the model fit (the pseudo $\mathrm{R}^{2}$ raises from 52.15 to 52.87 , with a $\chi^{2}=23.0, d f=1, p=.000$.), thus the impact of similarity in school-leaving status similarity is rather small. Other characteristics like gender, migrant status, or school performance are more important in predicting peer relations than future school-leaving status. It is likely that all these effects are overestimated by not taking into account the interdependence among dyads (Lubbers \& Snijders, 2007). As the effect of similarity in school-leaving status in our analysis is smaller than that of similarity in gender, migrant status, and school performance, we can conclude that the formation of friendship relations is only to a small extent based on future school-leaving status. Therefore, it is unlikely that our association between peers' school-leaving status and the probability of becoming an early school-leaver can be attributed to homophily.

\section{$<$ Table 4 about here $>$}

\section{Conclusions and discussion}

This paper addresses three research questions: do characteristics of peers at age 12 affect the risk of students of becoming an early school-leaver later on in education? Are there effects of both friends (those nominated by students) as well as popularity (those who nominated the students)? And can these effects be accounted for by peer selection based on homophily? Our results showed that both popularity and friendship correlate with early school-leaving. This is in line with findings by others (Diehl et al., 1998; Vandell \& Hembree, 1994) who found additive effects of the two measures on school adjustment. Peer characteristics such as gender, migrant status, peers' cognitive skills, and the socio-economic status of peers at age 12 do not affect the future risk of a student of leaving school early over and above the schoolleaver status of the peer. However, being popular among future early school-leavers as well as being friends with future early school-leavers are both associated with an increased risk of early school-leaving, although these effects are in part redundant. Also, being popular among regular school-leavers appears to protect against the risk of early school-leaving. In conclusion, our study confirms that peer acceptance can actually have a detrimental effect, if it is acceptance by the "wrong" crowd (Asher, MacEvoy, \& McDonald, 2008; Ream \& Rumberger, 2008).

One issue in studying peer influence is that peers select their friends based on similarity in various characteristics. This makes it difficult to differentiate between selection effects (similarity causes the formation of relationships) and true peer influence (relationships cause similarity). However, our robustness check of the peer selection process showed that while similarity in characteristics does play a 
role in the formation of peer relations, similarity in future school-leaving status influenced peer selection only very moderately.

The large and representative sample and our controls for alternative explanations of early schoolleaving inspire confidence in our results. Nevertheless, further research is needed to gain a better insight into the causal mechanisms behind the association between peer relations and peer characteristics on the one hand and students' risk of early school-leaving on the other. Although we provided some reassurance in showing that the selection of friends is not much affected by the peers' future school-leaving status, the question remains, of course, whether there is a true causal effect that makes students leave school early if they have peers who also leave school early. One way to address this issue would be by using longitudinal information of changes over time in peer relations and the characteristics of a respondent's peers as well as indicators of changes over time in school attachment. In that case one could use a Difference-inDifference model to address unobserved heterogeneity, and provide insight into how the process of the risk of early school-leaving develops in the course of the education career. Stochastic actor-based modelling for network dynamics (SIENA; Snijders, van de Bunt, \& Steglich, 2010; Steglich, Snijders, \& Pearson, 2010) could also be used to investigate the co-evolution of peer relations and scholastic attributes, to disentangle peer selection and peer influence while controlling for the dependence structure in networks. Unfortunately, this type of data is not available for the Netherlands, nor have we found them for other countries, as they would be very costly and time-consuming to gather. An alternative to this approach would be to use an Instrumental Variable (IV)-estimator or some form of natural experiment to estimate the causal effect. However, finding a strong instrument to reach this goal will be challenging. Adolescent peer affiliations with future early school-leavers seem to increase the risk of early school-leaving. At the same time, however, characteristics of the individual largely determine who is successful in school and who is not. This implies that policies to reduce early school-leaving should focus primarily on the individual, to tackle those at risk of leaving school-early. However, the relevance of group structures in secondary school should certainly not be overlooked. 
Appendix 1 The Dutch educational system

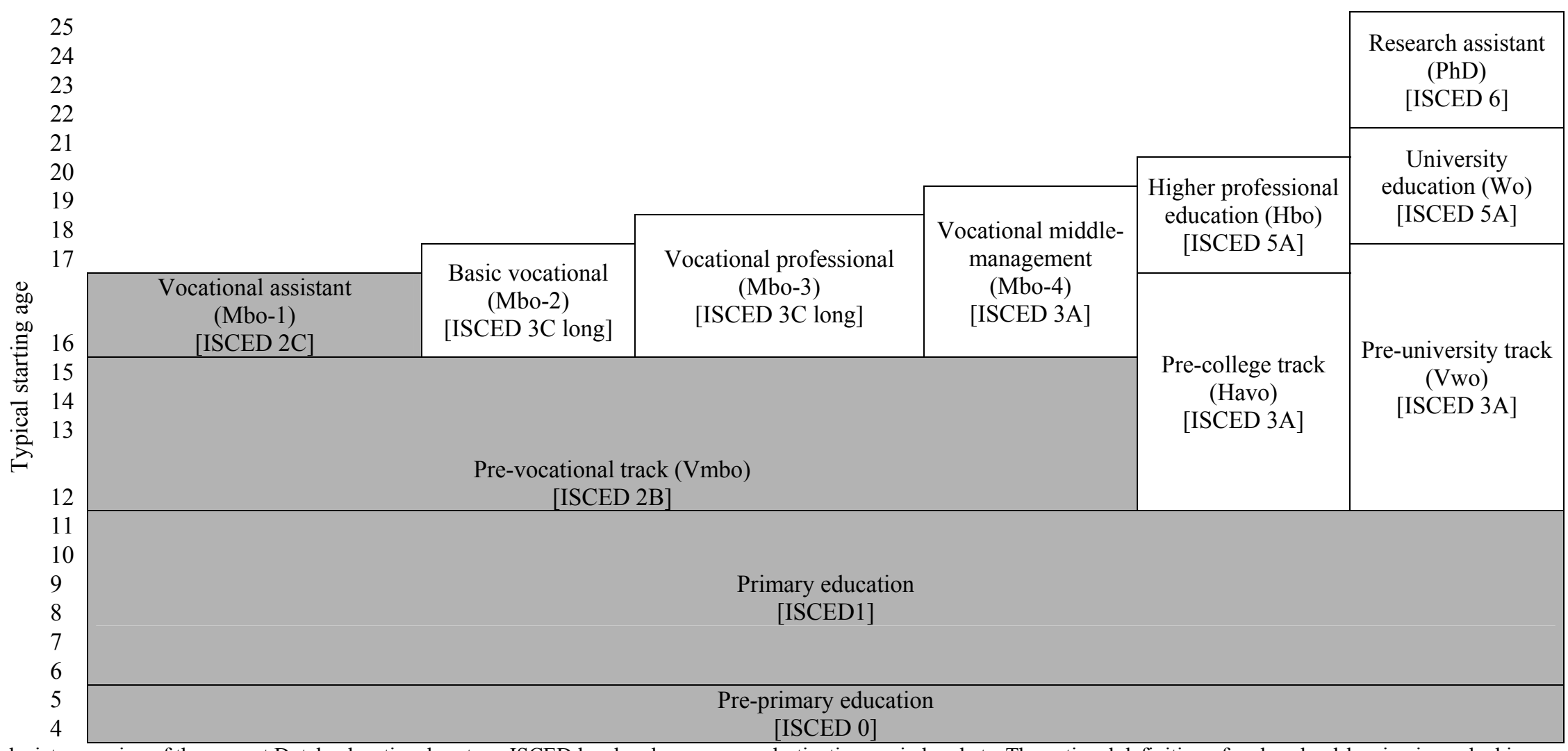

Note: Figure depicts mapping of the current Dutch educational system. ISCED level and programme destination are in brackets. The national definition of early school-leaving is marked in grey 
Appendix 2 Descriptive statistics of explanatory variables, by school-leaving status (standard deviations given in brackets)

\begin{tabular}{|c|c|c|c|c|c|c|c|}
\hline \multirow{2}{*}{$\begin{array}{l}\text { Student characteristics } \\
\end{array}$} & & \multicolumn{2}{|c|}{$\begin{array}{c}\text { Regular } \\
\text { school-leavers }\end{array}$} & \multicolumn{2}{|c|}{$\begin{array}{l}\text { Early school- } \\
\text { leavers }\end{array}$} & \multicolumn{2}{|c|}{ Total } \\
\hline & & & & & & & \\
\hline & \multicolumn{7}{|l|}{ Gender } \\
\hline & Male & \multicolumn{2}{|l|}{44.2} & \multicolumn{2}{|l|}{51.9} & \multicolumn{2}{|l|}{45.7} \\
\hline & Female & \multicolumn{2}{|l|}{55.8} & \multicolumn{2}{|l|}{48.1} & \multicolumn{2}{|l|}{54.3} \\
\hline & Migrant status & & & & & & \\
\hline & Migrant & \multicolumn{2}{|l|}{7.8} & \multicolumn{2}{|l|}{13.0} & \multicolumn{2}{|l|}{8.8} \\
\hline & Native & \multicolumn{2}{|l|}{92.2} & \multicolumn{2}{|l|}{87.0} & \multicolumn{2}{|l|}{91.2} \\
\hline & School performance & 0.63 & $(0.177)$ & 0.46 & $(0.167)$ & 0.60 & $(0.187)$ \\
\hline & School motivation & 0.62 & $(0.145)$ & 0.60 & $(0.165)$ & 0.62 & $(0.150)$ \\
\hline & Parental education & 14.18 & $(3.148)$ & 12.20 & $(3.358)$ & 13.81 & $(3.282)$ \\
\hline & Parental income & 10.23 & $(0.992)$ & 9.97 & $(1.122)$ & 10.18 & (1.023) \\
\hline & Parental communication & 0.54 & $(0.162)$ & 0.51 & $(0.175)$ & 0.53 & $(0.165)$ \\
\hline \multicolumn{8}{|l|}{ Popularity } \\
\hline & Number of nominations by regular school-leavers & 2.24 & $(1.581)$ & 1.54 & $(1.340)$ & 2.10 & $(1.562)$ \\
\hline & Number of nominations by early school-leavers & 0.37 & $(0.696)$ & 0.78 & $(0.946)$ & 0.45 & $(0.767)$ \\
\hline & $\%$ Males & 0.40 & $(0.470)$ & 0.45 & $(0.476)$ & 0.41 & $(0.472)$ \\
\hline & $\%$ Migrants & 0.07 & $(0.198)$ & 0.12 & $(0.265)$ & 0.08 & $(0.213)$ \\
\hline & Average School performance & 0.57 & $(0.237)$ & 0.42 & $(0.219)$ & 0.54 & $(0.241)$ \\
\hline & Average School motivation & 0.57 & $(0.206)$ & 0.53 & $(0.231)$ & 0.56 & $(0.212)$ \\
\hline & Average Parental education & 12.80 & $(4.668)$ & 10.99 & $(4.818)$ & 12.46 & $(4.750)$ \\
\hline & Average Parental income & 9.29 & $(3.007)$ & 8.84 & $(3.324)$ & 9.21 & $(3.074)$ \\
\hline & Average Parental communication & 0.49 & $(0.190)$ & 0.45 & $(0.205)$ & 0.48 & $(0.193)$ \\
\hline \multicolumn{8}{|l|}{ Friends } \\
\hline & Number of regular school-leaving friends & 2.23 & $(0.966)$ & 1.66 & $(1.048)$ & 2.12 & $(1.007)$ \\
\hline & Number of early school-leaving friends & 0.35 & $(0.624)$ & 0.78 & $(0.858)$ & 0.43 & $(0.696)$ \\
\hline & $\%$ Males & 0.41 & $(0.470)$ & 0.45 & $(0.469)$ & 0.42 & $(0.470)$ \\
\hline & $\%$ Migrants & 0.07 & $(0.186)$ & 0.11 & $(0.243)$ & 0.08 & $(0.199)$ \\
\hline & Average School performance & 0.59 & $(0.218)$ & 0.44 & $(0.210)$ & 0.56 & $(0.225)$ \\
\hline & Average School motivation & 0.58 & $(0.182)$ & 0.55 & $(0.213)$ & 0.57 & $(0.189)$ \\
\hline & Average Parental education & 13.26 & $(4.160)$ & 11.36 & $(4.511)$ & 12.90 & $(4.293)$ \\
\hline
\end{tabular}


Average Parental income

Average Parental communication

School*class level

Degree of urbanization

Percentage of migrants

Heterogeneity

Only pre-vocational track

All tracks

Only pre-college and pre-university tracks

Only pre-university track

Class size

$\begin{array}{cccccc}9.56 & (2.607) & 9.07 & (3.085) & 9.47 & (2.711) \\ 0.51 & (0.168) & 0.47 & (0.190) & 0.50 & (0.173) \\ & & & & & \\ 3.16 & (1.232) & 3.41 & (1.229) & 3.21 & (1.235) \\ 0.08 & (0.131) & 0.13 & (0.185) & 0.09 & (0.144) \\ & & & & & \\ 14.0 & & 40.5 & & 19.0 & \\ 70.1 & & 55.1 & & 67.2 & \\ 12.7 & & 3.7 & & 11.0 & \\ 3.2 & & 0.6 & & 2.7 & \\ 22.42 & (6.598) & 19.60 & (6.643) & 21.89 & (6.698) \\ & & & & & \end{array}$


Appendix 3 Zero-order correlations analyses

\begin{tabular}{|c|c|c|c|c|c|c|c|c|c|c|c|c|c|}
\hline & 1 & 2 & 3 & 4 & 5 & 6 & 7 & 8 & 9 & 10 & 11 & 12 & 13 \\
\hline \multicolumn{14}{|l|}{ 1. Early school-leaving } \\
\hline 2. Gender & 0.060 & & & & & & & & & & & & \\
\hline 3. Migrant status & 0.071 & 0.006 & & & & & & & & & & & \\
\hline 4. School performance & -0.351 & 0.023 & -0.129 & & & & & & & & & & \\
\hline 5. School motivation & -0.052 & -0.002 & 0.128 & 0.047 & & & & & & & & & \\
\hline 6. Parental education & -0.237 & 0.016 & -0.253 & 0.334 & 0.009 & & & & & & & & \\
\hline 7. Parental income & -0.101 & 0.028 & -0.103 & 0.116 & 0.003 & 0.220 & & & & & & & \\
\hline 8. Parental communication & -0.066 & -0.013 & -0.059 & 0.039 & 0.135 & 0.165 & 0.058 & & & & & & \\
\hline 9. Popularity & -0.067 & -0.053 & -0.040 & 0.056 & -0.002 & 0.063 & 0.038 & 0.022 & & & & & \\
\hline 10. Friends & -0.060 & -0.068 & -0.041 & 0.132 & 0.001 & 0.042 & 0.011 & 0.010 & 0.200 & & & & \\
\hline $\begin{array}{l}\text { 11. Popularity: Number of nominations by } \\
\text { regular school-leavers }\end{array}$ & -0.174 & -0.075 & -0.073 & 0.224 & 0.017 & 0.156 & 0.068 & 0.051 & 0.888 & 0.195 & & & \\
\hline $\begin{array}{l}\text { 12. Popularity: Number of nominations by } \\
\text { early school-leavers }\end{array}$ & 0.209 & 0.037 & 0.063 & -0.335 & -0.041 & -0.182 & -0.056 & -0.057 & 0.349 & 0.034 & -0.121 & & \\
\hline $\begin{array}{l}\text { 13. Friends: Number of nominations by } \\
\text { regular school-leavers }\end{array}$ & -0.222 & -0.095 & -0.093 & 0.376 & 0.031 & 0.187 & 0.070 & 0.061 & 0.161 & 0.736 & 0.361 & -0.388 & \\
\hline $\begin{array}{l}\text { 14. Friends: Number of nominations by } \\
\text { early school-leavers }\end{array}$ & 0.245 & 0.051 & 0.082 & -0.377 & -0.043 & -0.218 & -0.087 & -0.076 & 0.020 & 0.201 & -0.275 & 0.604 & -0.515 \\
\hline
\end{tabular}

Note. Correlations significant at the .01 level are reported in italics 
Appendix 4 Additional random effects model for the risk of early school-leaving based on reciprocal friendship

\begin{tabular}{|c|c|c|c|c|}
\hline Fixed effects & & (5a) & $(5 b)$ & (6) \\
\hline Intercept & & $2.629 * * *$ & $2.544 * * *$ & $2.579 * * *$ \\
\hline \multicolumn{5}{|c|}{$\begin{array}{l}\text { Individual level } \\
\text { predictors }\end{array}$} \\
\hline \multicolumn{5}{|l|}{$\begin{array}{l}\text { Student } \\
\text { characteristics }\end{array}$} \\
\hline & Gender & & & \\
\hline & Male & $.408 * * *$ & $.381 * * *$ & $.362 * * *$ \\
\hline & Female (ref). & & & \\
\hline & Migrant status & & & \\
\hline & Migrant & $-.345 * * *$ & $-.327 * * *$ & $-.341 * * *$ \\
\hline & Native (ref). & & & \\
\hline & School performance & $-2.827 * * *$ & $-2.773 * * *$ & $-2.688 * * *$ \\
\hline & School motivation & $-.475 * * *$ & $-.466 * *$ & $-.458 * *$ \\
\hline & Parental education & $-.086 * * *$ & $-.086^{* * *}$ & $-.084 * * *$ \\
\hline & Parental income & $-.104 * * *$ & $-.100 * * *$ & $-.100 * * *$ \\
\hline & Parental communication & $-.333 *$ & $-.319 *$ & $-.317 *$ \\
\hline \multicolumn{5}{|l|}{ Popularity } \\
\hline & Percentage of males & & & -.037 \\
\hline & Percentage of migrants & & & .153 \\
\hline & Average school performance & & & .134 \\
\hline & Average school motivation & & & .396 \\
\hline & Average parental education & & & .020 \\
\hline & Average parental income & & & .002 \\
\hline & Average parental communication & & & -.012 \\
\hline & $\begin{array}{l}\text { Number of nominations by } \\
\text { regular school-leavers }\end{array}$ & & & $-.134 * * *$ \\
\hline & $\begin{array}{l}\text { Number of nominations by } \\
\text { early school-leavers }\end{array}$ & & & $.129 * *$ \\
\hline \multicolumn{5}{|c|}{ Reciprocal friendship } \\
\hline & Percentage of males & .042 & -.044 & .069 \\
\hline & Percentage of migrants & .143 & -.071 & -.175 \\
\hline & Average school performance & .047 & .173 & .064 \\
\hline & Average school motivation & -.283 & -.205 & -.426 \\
\hline & Average parental education & -.010 & -.009 & -.019 \\
\hline & Average parental income & $-.069 *$ & -.060 & -.063 \\
\hline & Average parental communication & -.387 & -.372 & -.365 \\
\hline & $\begin{array}{l}\text { Number of friends among } \\
\text { regular school-leavers }\end{array}$ & & $-.100 * *$ & -.004 \\
\hline
\end{tabular}


Number of friends among

early school-leavers

School and class*class level predictors

Class level at age 12

Pre-vocational track (ref.)

Pre-college track

$\begin{array}{rrr}-.711 * * * & -.643 * * * & -.576 * * * \\ -.969 * * * & -.890 * * * & -.826 * * * \\ .092 * * * & .089 * * * & .084 * * * \\ .546 * * * & .664 * * * & .544 * *\end{array}$

Degree of urbanisation

Percentage of migrant students

$.546 * * * \quad .664 * * * \quad .544 * *$

Heterogeneity

Only pre-vocational track (ref.)

All tracks

Only pre-college and

pre-university track

Only pre-university track

$\begin{array}{ccc}-.254 * * * & -.219 * * & -.192 * * * \\ -.491 * * * & -.435 * * & -.390 * * \\ -.143 & -.126 & -.086 \\ -.003 & -.002 & -.001\end{array}$

Class size

$-.001$

\begin{tabular}{lccc}
\hline Random effects \\
\hline \multicolumn{5}{l}{} \\
\hline Variance at class level & -2.435 & -3.198 & -10.498 \\
Intraclass correlation & .026 & .012 & .000 \\
\hline
\end{tabular}


Tables and figures

Figure 1 Average number of nominations received by school-leaving status in year 2010/ 11

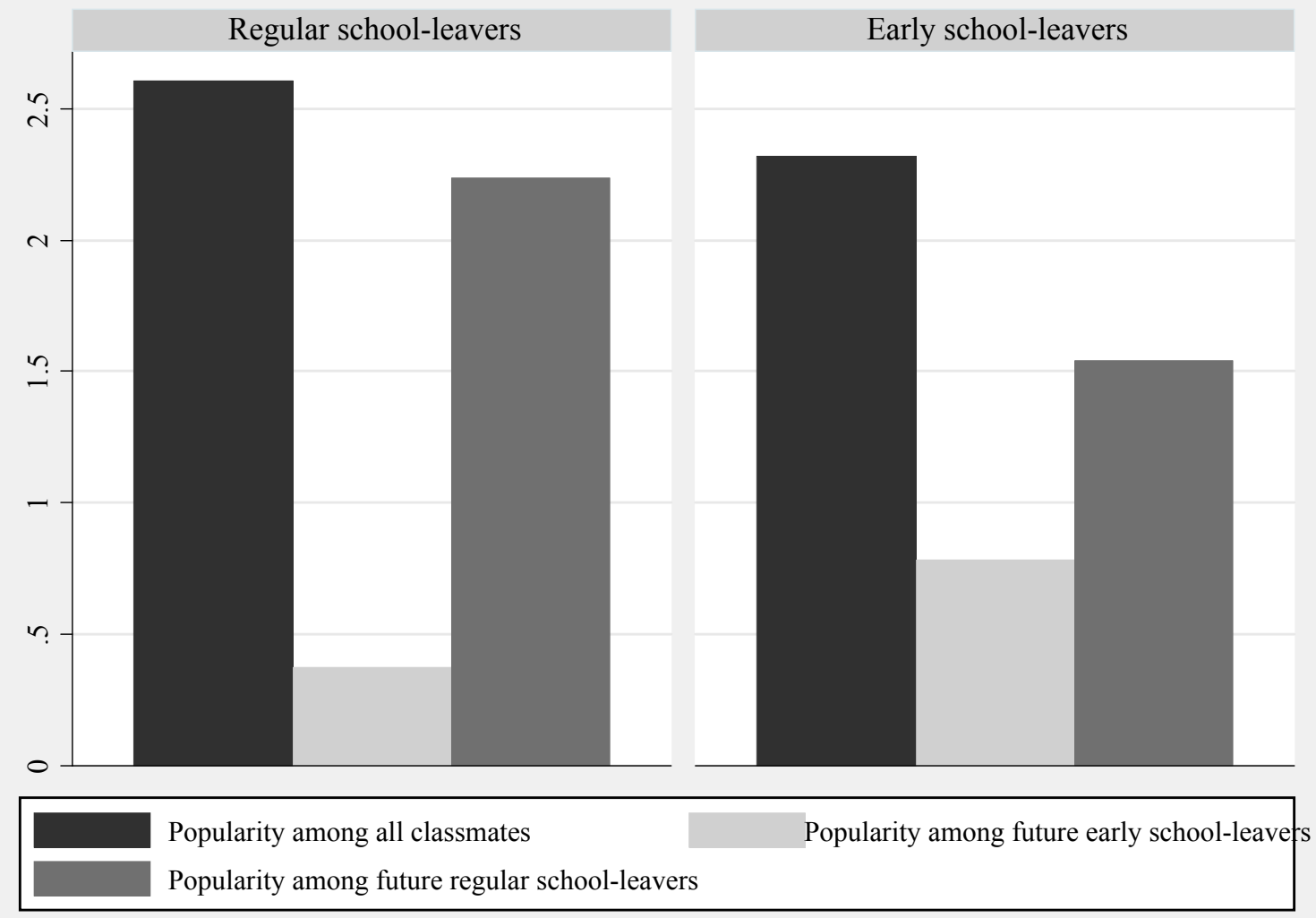


Figure 2 Average number of friends by school-leaving status in year 2010/ 11

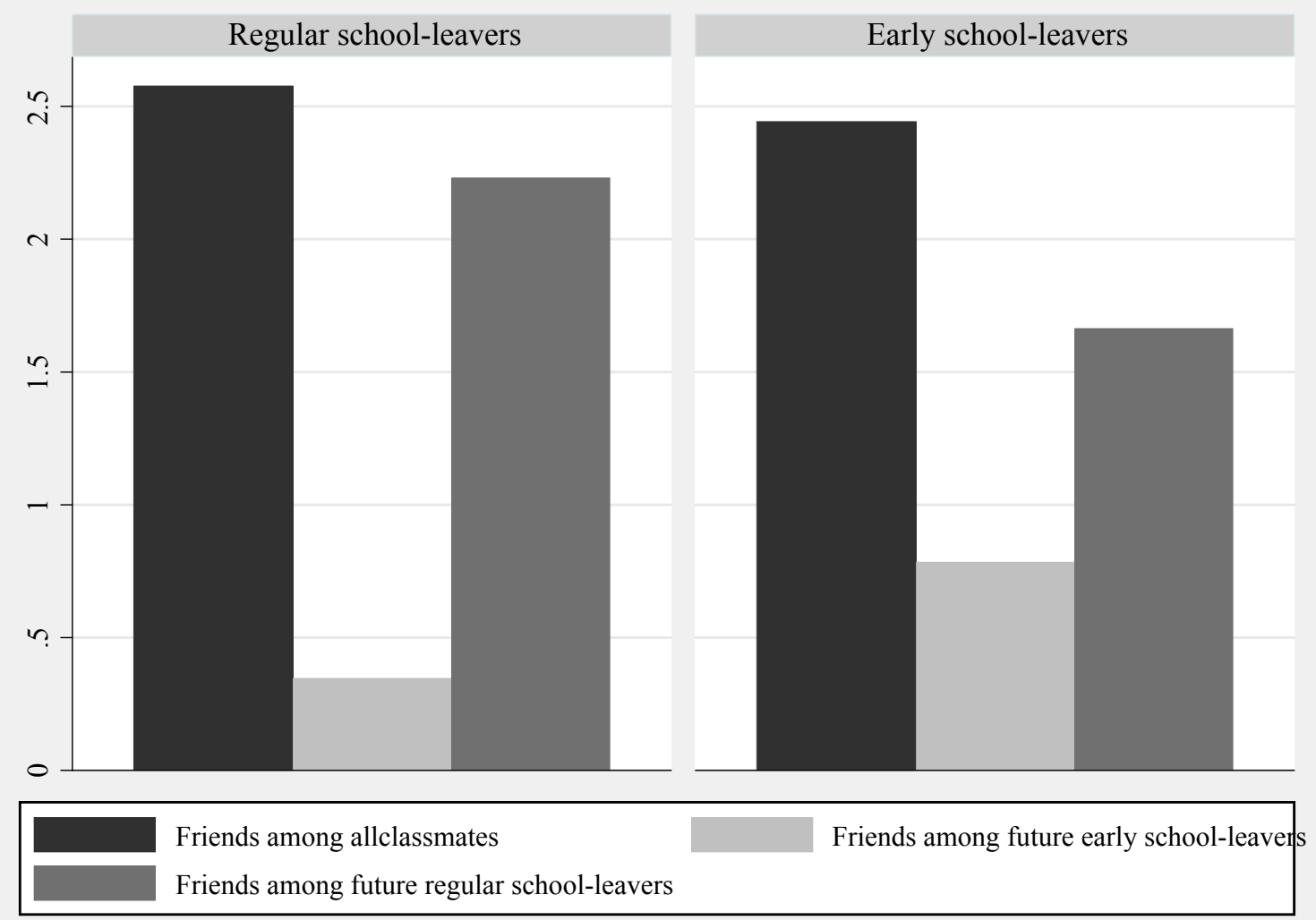


Table 1 Early school-leaving rates by track level in the first grade of Dutch secondary education and education level achieved in school year 2010/ 11(percentages in brackets)

\begin{tabular}{|c|c|c|c|c|}
\hline \multirow[b]{2}{*}{$\begin{array}{l}\text { Track level first grade in secondary } \\
\text { education }\end{array}$} & \multicolumn{2}{|c|}{ Diploma status $2010 / \sim 11$} & $\begin{array}{c}\text { Total early school- } \\
\text { leavers }\end{array}$ & \multirow[b]{2}{*}{ Total population } \\
\hline & $\begin{array}{c}\text { No diploma } \\
\text { at all }\end{array}$ & $\begin{array}{c}\text { Pre- } \\
\text { vocational } \\
\text { education or } \\
\text { vocational } \\
\text { assistant } \\
\end{array}$ & Total & \\
\hline Pre-vocational track & $\begin{array}{c}198 \\
(3.6)\end{array}$ & $\begin{array}{l}1,516 \\
(27.4)\end{array}$ & $\begin{array}{l}1,714 \\
(31.0)\end{array}$ & 5,524 \\
\hline Pre-college track & $\begin{array}{c}24 \\
(1.0)\end{array}$ & $\begin{array}{l}169 \\
(7.4)\end{array}$ & $\begin{array}{l}193 \\
(8.4)\end{array}$ & 2,296 \\
\hline Pre-university track & $\begin{array}{c}29 \\
(.9)\end{array}$ & $\begin{array}{l}124 \\
(4.0)\end{array}$ & $\begin{array}{l}153 \\
(5.0)\end{array}$ & 3,078 \\
\hline Total & $\begin{array}{c}251 \\
(2.3)\end{array}$ & $\begin{array}{r}1,809 \\
(16.6) \\
\end{array}$ & $\begin{array}{l}2,060 \\
(18.9) \\
\end{array}$ & $\begin{array}{l}10,898 \\
(100.0)\end{array}$ \\
\hline
\end{tabular}


Table 2 Random effects logit model for the risk of early school-leaving dependent on individual and peer characteristics (logits are reported).

\begin{tabular}{|c|c|c|c|c|c|c|c|}
\hline Fixed effects & & (1) & $(2 a)$ & $(2 b)$ & $(3 a)$ & $(3 b)$ & (4) \\
\hline Intercept & & $2.649 * * *$ & $2.659 * * *$ & $3.065 * * *$ & $2.548 * * *$ & $2.409 * * *$ & $2.450 * * *$ \\
\hline \multicolumn{8}{|c|}{$\begin{array}{l}\text { Individual level } \\
\text { predictors }\end{array}$} \\
\hline \multicolumn{8}{|c|}{$\begin{array}{ll}\begin{array}{l}\text { Student } \\
\text { characteristics }\end{array} & \\
& \text { Gender }\end{array}$} \\
\hline & $\begin{array}{l}\text { Male } \\
\text { Female (ref). } \\
\text { Migrant status }\end{array}$ & $.432 * * *$ & $.307 * * *$ & $.311^{* * *}$ & $.419 * * *$ & $428 * * *$ & $.348 * *$ \\
\hline & $\begin{array}{l}\text { Migrant } \\
\text { Native (ref). }\end{array}$ & $-.329 * * *$ & $-.339 * * *$ & $-.340 * * *$ & $-.343 * * *$ & $-.333 * * *$ & $-.343 * * *$ \\
\hline & School performance & $-2.818 * * *$ & $-2.630 * * *$ & $-2.594 * * *$ & $-2.791 * * *$ & $-2.745 * * *$ & $-2.625 * * *$ \\
\hline & School motivation & $-.478 * *$ & $-.473 * *$ & $-.463 * *$ & $-.476 * * *$ & $-.464 * *$ & $-.459 * *$ \\
\hline & Parental education & $-.088 * * *$ & $-.085 * * *$ & $-.083 * * *$ & $-.085 * * *$ & $-.085^{* * *}$ & $-.082 * * *$ \\
\hline & Parental income & $-.104 * * *$ & $-.104 * * *$ & $-.101 * * *$ & $-.104 * * *$ & $-.099 * * *$ & $-.098 * * *$ \\
\hline & Parental communication & $-.331 *$ & $-.286^{*}$ & $-.276^{*}$ & $-.322 *$ & $-.300 *$ & $-.274 *$ \\
\hline \multicolumn{8}{|l|}{ Popularity } \\
\hline & Percentage of males & & .145 & .079 & & & .097 \\
\hline & Percentage of migrants & & .044 & .015 & & & .003 \\
\hline & Average school performance & & $-.487 *$ & -.136 & & & -.505 \\
\hline & Average school motivation & & .064 & .093 & & & .092 \\
\hline & Average parental education & & $-.024 *$ & -.017 & & & .000 \\
\hline & Average parental income & & $.044^{*}$ & .033 & & & .033 \\
\hline & Average parental communication & & -.376 & -.349 & & & -.429 \\
\hline & $\begin{array}{l}\text { Number of nominations by } \\
\text { regular school-leavers } \\
\text { Number of nominations by } \\
\text { early school-leavers }\end{array}$ & & & $\begin{array}{l}-.131 * * * \\
.159 * * *\end{array}$ & & & $\begin{array}{l}-.120 * * * \\
.101 * *\end{array}$ \\
\hline
\end{tabular}


Percentage of males

Percentage of migrants

$\begin{array}{lll}.022 & -.037 & -.057\end{array}$

Average school performance

$\begin{array}{lll}.071 & .081 \quad .075\end{array}$

Average school motivation

$\begin{array}{lll}.067 & .075 & .626\end{array}$

Average parental education

$\begin{array}{lll}.031 & -.021 \quad-.054\end{array}$

Average parental income

Average parental communication

$-.040 * * * \quad-.032 * * \quad-.033 *$

Number of friends among

regular school-leavers

$052 * \quad .023 \quad-.005$

Number of friends among

early school-leavers

$\begin{array}{lll}-.069 & -.069 & .062\end{array}$

$-.012 \quad .047$

$232 * * *$

$.168 * * *$

School and class*class level predictors

\begin{tabular}{|c|c|c|c|c|c|c|}
\hline Class level at age 12 & & & & & & \\
\hline \multicolumn{7}{|l|}{ Pre-vocational track (ref.) } \\
\hline Pre-college track & $-.709 * * *$ & $-.658 * * *$ & $-.573 * * *$ & $-.697 * * *$ & $-.620 * * *$ & $-.575 * * *$ \\
\hline Pre-university track & $-.968 * * *$ & $-.887 * * *$ & $-.811 * * *$ & $-.938 * * *$ & $-.870 * * *$ & $-.815^{* * *}$ \\
\hline Degree of urbanisation & $.092 * * *$ & $.094 * * *$ & $.087 * * *$ & $.095 * * *$ & $.095 * * *$ & $.090 * * *$ \\
\hline Percentage of migrant students & $.634 * *$ & $.499 * *$ & $.475^{*}$ & $.464 *$ & .381 & .369 \\
\hline \multicolumn{7}{|l|}{ Heterogeneity } \\
\hline \multicolumn{7}{|l|}{ Only pre-vocational track (ref.) } \\
\hline All tracks & $-.255 * * *$ & $-.211 * * *$ & $-.175 * *$ & $-.226 * * *$ & $-.176 * *$ & $-.157 * *$ \\
\hline $\begin{array}{l}\text { Only pre-college and } \\
\text { pre-university track }\end{array}$ & $-.486 * * *$ & $-.422 * *$ & $-.363 * *$ & $-.443 * * *$ & $-.370 * *$ & $-.339 * *$ \\
\hline Only pre-university track & -.138 & -.069 & -.059 & -.084 & -.038 & -.033 \\
\hline Class size & -.003 & -.000 & -.000 & -.002 & .002 & -.001 \\
\hline \multicolumn{7}{|l|}{ Random effects } \\
\hline Variance at class level & -2.437 & -2.569 & -11.110 & -2.572 & -4.674 & -11.800 \\
\hline Intraclass correlation & .026 & .023 & .000 & .023 & .002 & .000 \\
\hline
\end{tabular}

Notes: Sample size is 10,898 students. Data clustered in 576 school*class groups. ${ }^{* * *}=\mathrm{p}<.01 * *=\mathrm{p}<.05 * \mathrm{p}<.10$ 
Table 3 Descriptives for dyadic similarity by school-leaving status

\begin{tabular}{|c|c|c|c|c|c|}
\hline & & $\begin{array}{l}\text { Percentage } \\
\text { of similar } \\
\text { peers } \\
\end{array}$ & $\begin{array}{r}\text { Percentas } \\
\text { peers } \\
\text { relat }\end{array}$ & $\begin{array}{l}\text { of similar } \\
\text { by peer } \\
\text { ionship }\end{array}$ & \\
\hline & & Total & $\begin{array}{c}\text { One } \\
\text { indicated } \\
\text { the other } \\
\text { as a peer } \\
\text { they } \\
\text { liked }\end{array}$ & $\begin{array}{c}\text { No } \\
\text { relationship } \\
\text { between } \\
\text { peers } \\
\end{array}$ & T-value \\
\hline \multirow[t]{8}{*}{$\begin{array}{l}\text { Similarity within } \\
\text { dyads in: }\end{array}$} & Gender & .578 & .958 & .526 & $-99.586 *$ \\
\hline & Migrant status & .776 & .795 & .774 & $-5.664 *$ \\
\hline & School performance & .364 & .397 & .360 & $-8.617^{*}$ \\
\hline & School motivation & .228 & .248 & .226 & $-5.812 *$ \\
\hline & Parental education & .359 & .378 & .357 & $-4.841 *$ \\
\hline & Parental income & .227 & .234 & .226 & -1.962 \\
\hline & Parental communication & .236 & .247 & .235 & -3.099 \\
\hline & Early school-leaving status & .762 & .772 & .760 & -3.0896 \\
\hline
\end{tabular}

Notes: Sample size is $113, .835$ dyads. ${ }^{*} \mathrm{p}<.001$ 
Table 4 Random effects logit model for the probability of nominating a peer as someone they like (bcoefficients reported)

\begin{tabular}{|c|c|c|c|}
\hline \multicolumn{2}{|c|}{ Fixed effects } & (1) & (2) \\
\hline \multicolumn{2}{|c|}{ Intercept } & $-4.718^{* *}$ & $-4.805^{* *}$ \\
\hline \multicolumn{4}{|c|}{$\begin{array}{l}\text { Individual level } \\
\text { predictors }\end{array}$} \\
\hline \multicolumn{4}{|c|}{ Dyadic similarity in: } \\
\hline & Gender & $3.038^{* *}$ & $3.039 * *$ \\
\hline & Migrant status & $.149 * *$ & $.145^{* *}$ \\
\hline & School performance & $.144^{* *}$ & $.145^{* *}$ \\
\hline & School motivation & $.051^{* *}$ & $.052 * *$ \\
\hline & Parental education & $.073^{* *}$ & $.080 * *$ \\
\hline & Parental income & $.041 *$ & $.041^{*}$ \\
\hline & Parental communication & $.046^{*}$ & $.047^{*}$ \\
\hline & Early school-leaving status & & $.112 * *$ \\
\hline \multicolumn{4}{|c|}{ Random effects } \\
\hline \multicolumn{2}{|c|}{ Variance at class level } & -3.589 & -3.578 \\
\hline \multicolumn{2}{|c|}{ Intraclass correlation } & .008 & .008 \\
\hline \multicolumn{2}{|l|}{$\chi^{2}$} & $52.15^{* *}$ & $52.87 * *$ \\
\hline
\end{tabular}

Note: Sample size is 113,835 dyads. ${ }^{* *} \mathrm{p}<.001,{ }^{*} \mathrm{p}<.01$ 
Literature

Asher, S. A., MacEvoy, J. P., \& McDonald, K. L. (2008). Children's peer relations, social competence, and school adjustment: A social tasks and social goals perspective. In M. L. Maehr, S. Karabenick \& T. Urdan (Eds.), Advances in motivation and achievement. Amsterdam: Elsevier.

Bandura, A. (1977). Social Learning Theory. New York: Prentice Hall.

Beckers, I., \& Traag, T. (2005a). Jongeren op de arbeidsmarkt. Sociaaleconomische trends, 1, 22-26.

---. (2005b). Met een startkwalificatie betere kansen op de arbeidsmarkt. Sociaaleconomische trends, 2005(4), 23-28.

Bosker, R. J., Van Der Velden, R. K. W., \& Hofman, W. H. A. (1985). Een generatie geselecteerd. Deel I: De loopbanen. Groningen: RION.

Buhs, E. S., \& Ladd, G. W. (2001). Peer rejection as antecedent of young children's school adjustment: An examination of mediating processes. . Developmental Psychology, 37(550-560).

Bukowski, W. M., \& Hoza, B. (1993). Popularity and friendship: Issues in theory, measurement, and outcome. In W. Damon \& B. P. Laursen (Eds.), New directions for child development: Vol. 60. Close friendships in adolescence (pp. 23-37). San Francisco.: Jossey-Bass.

Cairns, R. B., Cairns, B. D., \& Neckerman, H. J. (1989). Early school dropout: configurations and determinants. Child Development, 60, 1437-1452.

Diehl, D. S., Lemerise, E. A., Caverly, S. L., Ramsay, S., \& Roberts, J. (1998). Peer relations and school adjustment in ungraded primary children. . Journal of Educational Psychology, 90(506-515).

Farmer, T. W., Estell, D. B., Leung, M.-C., Trott, H., Bishop, J., \& Cairns, B. D. (2003). Individual characteristics, early adolescent peer affoliations, and school dropout: an examination of aggressive and popular group types. Journal of School Psychology, 41, 217-232.

Furrer, C., \& Skinner, E. (2003). Sense of relatedness as a factor in children's academic engagement and performance. Journal of Educational Psychology, 95(1), 148-162.

Hermans, H. J. M. (1970). A questionnaire measure of achievement motivation. The Journal of Applied Psychology, 54, 353-363.

Hustinx, P. W. J., Kuyper, H., M.P.C. Van der Werf, M. P. C., \& Dijkstra, P. (2009). Achievement motivation revisited: New longitudinal data to demonstrate its predictive power. Educational Psychology, 29, 561-582.

Hymel, S., Comfort, C., Schonert-Reichel, K., \& McDougall, P. (1996). Academic failure and school dropout: The influence of peers. In J. Juvonen \& K. R. Wentzel (Eds.), Social motivation: Understanding children's school adjustment. Cambridge: Cambridge University Press.

Kuyper, H., Dijkstra, P., Buunk, A. P., \& Werf, M. P. C. v. d. (2011). Social comparisons in the classroom: An investigation of the better than average effect among secondary school children. Journal of School Psychology, 49, 25-53.

Kuyper, H., Lubbers, M. J., \& Van der Werf, M. P. C. (2003). VOCL'99-1: Technisch rapport. Groningen: GION.

Kuyper, H., Werf, M. P. C. v. d., \& Lubbers, M. J. (2000). Motivation, meta-cognition and selfregulation predictors of long term educational attainment. Educational Research and Evaluation, 6(181-205).

Ladd, G. W., Kochenderfer, B. J., \& Coleman, C. C. (1997). Classroom Peer Acceptance, Friendship, and Victimization: Destinct Relation Systems That Contribute Uniquely to Children's School Adjustment? Child Development, 68(1181-1197).

Lubbers, M. (2004). The social fabric of the classroom. Peer relations in secondary education. . Groningen: GION.

Lubbers, M. J., \& Snijders, T. A. B. (2007). A comparison of various approaches to the exponential random graph model: A reanalysis of 102 student networks in school classes. Social Networks, 29, 489-507.

Lubbers, M. J., Van der Werf, M. P. C., \& Kuyper, H. (2009). Social comparison with friends versus non-friends. European Journal of Social Psychology, 39, 52-68. 
Lubbers, M. J., Van der Werf, M. P. C., Snijders, T. A. B., Creemers, B. P. M., \& Kuyper, H. (2006). The impact of peer relations on academic progress in junior high. Journal of School Psychology, 44, 491-512.

McPherson, M., Smith-Lovin, L., \& Cook, J. M. (2001). Birds of a feather: Homophily in social networks. Annual Review of Sociology, 27, 415-444.

OECD. (2007). Education at a glance. Paris: OECD.

Patrick, H., Ryan, A. M., \& Kaplan, A. (2007). Early adolescents' perceptions of the classroom social environment, motivational beliefs, and engagement. Journal of Educational Psychology, 99(1), 83-98.

Ream, R. K., \& Rumberger, R. W. (2008). Student engagement, peer social capital, and school dropout among Mexican American and Non-Latino white students. Sociology of Education, 81, 109-139.

Risi, S., Gerhardstein, R., \& Kistner, J. (2003). Children's Classroom Peer Relationships and Subsequent Educational Outcomes Journal of Clinical Child \& Adolescent Psychology 32(3), 351-361.

Rumberger, R. W. (1987). High school drop-outs: A review of issues and evidence. Review of Educational Research, 87(2), 101-121.

Snijders, T. A. B., van de Bunt, G. G., \& Steglich, C. E. G. (2010). Introduction to actor-based models for network dynamics. Social Networks, 32(44-60).

Steglich, C. E. G., Snijders, T. A. B., \& Pearson, M. (2010). Dynamic Networks and Behavior: Separating Selection from Influence. Sociological Methodology, 40(329-393).

Thornberry, T. P., Moore, M., \& Christenson, R. L. (1985). The Effect of Dropping out of high school on subsequent criminal behavior. Criminology, 23, 3-18.

Traag, T., Marie, O., \& Van Der Velden, R. K. W. (2010). Social Bonding, Early School Leaving, and Delinquency.

Traag, T., \& Van der Velden, R. (2011). Early school-leaving in the Netherlands: The role of family resources, school composition and background characteristics in early school-leaving in lower secondary education. Irish Education Studies, 30(1).

Vandell, D. L., \& Hembree, S. E. (1994). Peer social status and friendship: Independent contributors to children's social and academic adjustment. . Merrill-Palmer Quarterly: Journal of Developmental Psychology, 40(4), 461-477.

Vitaro, F., Larocque, D., Janosz, M., \& Tremblay, R. E. (2001). Negative Social Experiences and dropping out of school. Educational Psychology, 21(4), 401-414.

Walters, K., \& Bowen, G. L. (1997). Peer group acceptance and academic performance among adolescents participating in a dropout prevention program. Child and Adolecent Social Work Journal, 14(6), 413-426.

Wentzel, K. R. (1996). Introduction. New perspectives on motivation at school. . In J. Juvonen \& K. R. Wentzel (Eds.), Social motivation: Understanding children's school adjustment. Cambridge: Cambridge university press.

---. (2003). Sociometric Status and Adjustment in Middle School: A Longitudinal Study. Journal of Early Adolescence, 23, 5-28.

Zettergren, P. (2003). School adjustment in adolescence for previously rejected, average and popular children. British Journal of Educational Psychology, 73, 207-221. 